\title{
Development of Strenght Training Models for Soccer Players Age 12-16 on Arema Indonesia
}

\author{
Muhammad Hazbeehan ${ }^{1,}$ Moch. Yunus ${ }^{2, *}$ Taufik Taufik ${ }^{3}$ \\ 1,2,3 Department of Sport Coaching, Faculty of Sport Sciences, Universitas Negeri Malang, Malang, East Java, \\ Indonesia \\ "Corresponding author. Email: moch.yunus.fik@um.ac.id
}

\begin{abstract}
The study aims to develop an android application-based strength training media for Diklat Arema Indonesia and Training soccer athletes. This study uses the development design research method developed by Borg \& Gall (1983). The subjects of this study were Arema Indonesia and training soccer athletes from the age of 12-16 years with a group test of 12 athletes consisting of 6 athletes each offline and 6 athletes online, as well as a large group test of 23 athletes offline, and 3 product validators, namely 2 physic expert and 1 media expert. The results of this study indicate that the product is very valid with the percentage of needs analysis results, as many as $92.3 \%$ of the 13 athletes agree that the soccer strength training material is presented in the form of an android application. The level of product validity of the results of the physic expert 1 and 2 obtained $82 \%$, the results of the media expert test validation obtained $75 \%$, the small group test obtained $80 \%$ and the large group test obtained $88.68 \%$. The conclusion obtained from this research and development is that the product is feasible and safe to use in training activities.
\end{abstract}

Keywords: Arema, exercise, strength training, soccer

\section{INTRODUCTION}

Sport is a series of systematic physical activity and involves the body's energy system that affects a person's physical fitness potential. In sports, sports are divided into several parts, including; educational sports, recreational sports, and achievement sports. Developing all the potential of athletes in a measurable and systematic way in the form of competitions to achieve an achievement on a regular basis with the support of sports science and technology is a feature of achievement sports. Athletes as sportsmen are required to participate in all forms of training systematically with full dedication to achieve achievement.

Several achievement sports, ranging from athletics, big ball sports, small ball sports, and others. In Southeast Asia, children and adults love soccer, which is an attractive sport. The sport that is played the most by the Indonesian people because it is the most popular is football [1]. "The Round Skin" has also been known as a popular sport in Indonesia. With the special advantages of Indonesian players, namely fast, agile, and superior one by one $(1 \mathrm{v} 1)$ where the geographical and sociological culture also supports, namely the tropics, respect for the hierarchy, and high family ties [2].
The achievements of Indonesian football in the international arena are very concerning. It has been proven that in the last few years, for competitions like Southeast Asia, the Indonesian national team must work hard to hope to reach the main podium. Perhaps the record for the U16, U19, U22 Age 12-16 Years team has won the title in the last 10 years [3]. In line with the state of the Indonesian senior national team, namely battered, weak, less reliable, are the right words for him at this time. Various factors cause the peak performance of our players, which should be at the senior age, but at the age of 12-16 years, the physical training provided to athletes is inadequate or not directed. Inadequate types of exercise, for example at an early age, have been given the same portion as adults. In the end, the peaking of athletes with such soccer training was not as expected, namely at the age of 12-16 years, due to athlete management problems and physiological limitations [4].

The soccer team in Indonesia in tackling this, especially the soccer school because it has the authority in early childhood development, it is necessary to have a systematic training android application. Training development using the Long Term Athlete Development (LTAD) model is the right step, namely in principle sports can be classified into 7 specialization models, 
including: (a) active start, (b) fundamental, (c) learning to train, (d) training to train, (e) training to compete, (f) training to win, (g) active for life [5]. The LTAD model was introduced with the aim of addressing the interaction between growth, maturity, and training [6]. The application of LTAD is also related to the age of a person's growth and development, namely training based on his age category. The 12-16 year age category is called training to train. This physical exercise model includes flexibility, aerobic-anaerobic endurance, agility, strength, balance, proper nutrition, and prevention of sports injuries [7].

The essence of exercise is the process of movement carried out by individuals or groups in a measurable, systematic, and sustainable manner to achieve maximum achievement [8]. The anatomy of soccer players affects the performance of athletes when competing. Preparation for competition in team sports involves skill acquisition, tactical development, mental preparation and physical training. Football requires its players to prepare almost all aspects of physical fitness [9]. At its most basic level, football seems to be a game of non-stop motion. Where in the senior age game consists of two 45-minute halves, while in leagues with younger players, the duration of each half is shorter. In Laws of the Game according to IFAB, the size of the field with a length of $100 \mathrm{~m}-120$ $\mathrm{m}$ and a minimum width of $45 \mathrm{~m}-90 \mathrm{~m}$ with a specified time makes athletes physically have to work harder [10]. Strength, endurance, speed are integral components that cannot be separated. For this reason, muscle strength which is the basis for creating optimal physical fitness needs to be trained [11]. There are 6 big muscles that need to be trained by soccer athletes to improve their performance, namely: (1) arms, (2) shoulders \& neck, (3) chest, (4) back \& hips, (5) abdomen, (6) legs [9]. Then the next step is to join the muscles to function as part of the whole system. By incorporating a full body training device it helps in coordinating the body during random actions that occur every few seconds in a soccer game [9]. Factors that influence strength include (1) muscle potential, namely the amount of muscle strength used in one work, (2) utilization of muscle potential, namely utilizing all muscle potential to contract, (3) technique, because with the right technique it can maximize muscle potential and minimize injury [12].

Periodization of training is an athlete's initial foundation for starting an initial training program. Strength training includes (1) anatomical adaptation, (2) maximum strength, (3) power. In the anatomical adaptation phase for junior ages (12-16 years) it is carried out 9-12 weeks with an exercise intensity of $40-65 \%$ of 1 maximum repetition [12]. In the maximum strength phase, 3 sets and 4-6 repetitions are carried out with training loads between $75 \%-85 \%$. In the power phase, the volume of exercise is higher with the intensity of the exercise. In soccer, movements such as kicking, running, and jumping in this phase are increased at optimal speed.

The Football School in Malang, Arema Indonesia Training and Education in particular has students whose majority are aged 12-16 years. At this age, children have experienced puberty. Puberty is a period of dynamic development characterized by rapid changes in body size, shape and composition [13]. Their characteristics are that they have great physical growth, and have begun to express their freedom and some of their rights to be expressed.

LTAD-based strength training has various age levels, ranging from 4-6 years old (active start), 6-9 years old (fundamentals), 9-12 years old (Learning to Train), 1216 years old (training to train), ages 16-20 years (Training to Compete), and ages 19 years and over is called training to win. The age of 12-16 years (training to train) includes the emphasis on technique with correct movements to the use of weights regularly and the majority of athletes are unstable in their performance if they skip this stage of the period [5]. Media as a supporting tool is needed in the application of strength training. Android-based online training media is recommended to overcome the problems being faced. The visualized form of the model and training program makes it easier for athletes to help develop their physical abilities. Implementing the program is suitable to use a participatory, contextual, and educational collaborative approach, through the stages of socialization, mentoring, monitoring and evaluation [14]. Android applications are needed to practice during this pandemic, as according to The android application is a medium that can help to make it easier for students, college students, and the general public to practice independently outside of their training schedule[15].

Based on the needs analysis as a first step for observation to 1 (one) coach with interviews and to athletes by being distributed in the form of a googlebased questionnaire, it was found that 84.6 percent of coaches had given material about strength training, as many as 76.5 percent of their strength conditions were classified as moderate, as many as 100 percent of athletes feel the need for strength training, as many as 61.5 percent of athletes' impressions of strength training so far, as many as 92.3 percent of athletes want media in the form of strength application videos. Against the background, the researchers attempted to make a decision to conduct research and development entitled "Strength Training for Soccer Players Age 12-16 Years Arema Indonesia". 


\section{METHOD}

This study was designed according to the objectives achieved. Research \& Development (R\&D) is the development design model used [16]. There are several stages in this design, including; (1) Research and data collection phase, (2) Planning phase, (3) Initial product format development phase, (4) Initial field trial phase, (5) Test result revision phase, (6) Field trial phase, (7) The stage of perfecting the product from the field test results, (8) The stage of field testing, (9) The stage of perfecting the final product, (10) The stage of dissemination and implementation.

Research subjects, among others; (1) The subject of the initial needs analysis is soccer players aged 12-16 years of training Arema Indonesia, (2) The subject of the evaluation consists of 2 (two) physicists and 1 (one) media expert, (3) The subject of field testing (small group ) consisted of 6 - 12 Arema Indonesia Education and Training soccer players, (4) Field test subjects (large group) consisted of 23 Arema Indonesia Training and Education soccer players.

The type of data used is development that uses primary data by involving active participation by researchers, where this data is obtained directly through survey activities, observations, questionnaires, and personal interviews, and the acquisition of available sources using secondary data.

The data collection method used a test technique that refers to the physical and psychomotor domains. In the psychomotor domain by testing the basic abilities of general movement and skills. Physical realm, namely test and measurement techniques. Both of these domains are found in the exercise evaluation menu on the android application. Data collection was carried out at Mulyagung Field, Sengkaling on June 15, 2021.

The instrument used in the research on developing a strength training model for soccer players aged 12-16 years using the android application at the Arema Indonesia Training and Education was initial observations using interviews and questionnaires for needs analysis, questionnaires were used to determine the results of field trials, namely small groups and large groups. As well as questionnaires for experts, namely from 2 (two) physicists and 1 (one) media expert.

Data analysis techniques on the development of strength training for soccer players aged 12-16 years Arema Indonesia using a Likert scale. This technique serves to analyze the opinions, perceptions, and attitudes of a person regarding social phenomena. This social phenomenon is considered as a research variable. Variables will be measured, then converted into variable indicators, then these indicators will be used as a reference in the preparation of instruments in the form of questions. (4) strongly agree, (3) agree, (2) undecided, (1) disagree is the level of answers to Likert scale questions [17].

Descriptive quantitative analysis percentage is the formula used in processing the data, stated in Equation (1)

$\mathrm{V}=\frac{T S E V}{S-\max } \times 100 \%$

To facilitate the conclusion of the percentage analysis, the criteria for product quality were (1) very valid (75.01$100 \%)$, (2) valid (50.01-75\%), (3) invalid (25.01-50\%), and (4) very invalid (0-25\%) [18].

\section{RESULTS}

\subsection{Identifying Problems and Establishing Troubleshooters}

Identifying problems, determining problem solving by observing an event during this pandemic, are Arema Indonesia training and training needed and can be carried out in the field? When it seems that they cannot carry out training in the field, the right solution to overcome this problem is to use an android application on their related gadgets so that the application of soccer strength training can be done at home.

\subsection{Conducting Preliminary Study and Needs Analysis}

At this stage, researchers collect data by distributing questionnaires to athletes in the form of google forms and interviews with soccer coaches at Arema Indonesia Education and Training, as well as obtaining data that their soccer training in this pandemic condition is only in the field and there is no supporting media for athletes to help practice in the field. at home, and the coach also wants individual training in the form of physical strength training at home that is easy for athletes to use. Based on the needs analysis of athletes using a google form-based questionnaire distributed, it was found that $92.3 \%$ of the 13 athletes agreed that soccer strength training materials were presented in the form of an android application.

\subsection{Setting Research Objectives Development and Product Specification}

Researchers develop media aimed at facilitating students to practice (learn) in training and at home using android application-based media. Utilization of android application-based media in physical training of soccer strength so that students can repeat soccer strength movements independently with supporting visualization, and it is easier to understand the training program material according to the training objectives to be achieved.

The main purpose of this application media is in terms of the success of the process of delivering training 
materials to athletes by paying attention to user needs, namely; (1) Training media can help athletes receive material easily and clearly, (2) The resulting training media has training materials that are in accordance with the training process carried out at Arema Indonesia Training and Education. The product that will be developed is about strength training in soccer in the form of an android application. The product specifications were stated in Table 1.

Table 1. Product specifications

\begin{tabular}{|c|c|c|}
\hline Concept & Variable & Indicator \\
\hline $\begin{array}{l}\text { Android } \\
\text { application } \\
\text { (soccer } \\
\text { strength } \\
\text { training } \\
\text { media) }\end{array}$ & $\begin{array}{l}\text { 1. Exercise } \\
\text { videos } \\
\text { 2. Exercise } \\
\text { program } \\
\text { 3. Exercise } \\
\text { evaluation }\end{array}$ & $\begin{array}{l}\text { 1. Athletes are able to } \\
\text { understand the training } \\
\text { model in the training } \\
\text { video } \\
\text { 2. Athletes are able to } \\
\text { implement a soccer } \\
\text { training program } \\
\text { independently } \\
\text { 3. Athletes are able to } \\
\text { evaluate themselves by } \\
\text { testing their strength } \\
\text { abilities }\end{array}$ \\
\hline
\end{tabular}

\subsection{Developing the Initial Product Model}

The initial product produced is in the form of an android application while the form of the application is the initial menu display, namely exercise videos, exercise programs, and exercise evaluations. The exercise video contains soccer strength movements, a circuit training program, namely the anatomical adaptation phase, maximum strength, and power, and an exercise evaluation consisting of various forms of soccer strength tests to determine the development of athlete's strength.

\subsection{Expert Trial or Initial Product Evaluation and Revision}

Once the initial product is developed, it needs to be validated by experts. The experts involved are 2 (two) physical experts using a questionnaire that has 3 (three) indicators, namely suitability, clarity, and accuracy. Consists of 52 questions. The data from the evaluation of physicists 1 (one) and 2 (two) were presented in Table 2.

Table 2. Physicist Validation Result (Phase 1)

\begin{tabular}{|l|l|l|l|l|l|}
\hline No & Aspect & \multicolumn{2}{|c|}{ Appropriateness } & Average & Category \\
\cline { 3 - 5 } & & $\begin{array}{c}\text { Expert } \\
\mathbf{1}\end{array}$ & $\begin{array}{c}\text { Expert } \\
\mathbf{2}\end{array}$ & & \\
\hline 1 & $\begin{array}{l}\text { Exercise } \\
\text { programs }\end{array}$ & $75 \%$ & $77 \%$ & $76 \%$ & $\begin{array}{l}\text { Very } \\
\text { valid }\end{array}$ \\
\hline 2 & $\begin{array}{l}\text { Exercise } \\
\text { videos }\end{array}$ & $57 \%$ & $64 \%$ & $61 \%$ & Valid \\
\hline 3 & $\begin{array}{l}\text { Exercise } \\
\text { evaluation }\end{array}$ & $75 \%$ & $75 \%$ & $75 \%$ & Valid \\
\hline \multicolumn{3}{|l|}{ Average } & $70.6 \%$ & Valid \\
\hline
\end{tabular}

Although the stage I validation of the two validators is quite valid, his suggestions and responses are directly proportional to each other which requires revision, namely; 1) the need to add procedures for implementation, 2) add a variety of exercises, 3) and an exercise program that is easier and more efficient to use. The result of validation phase 2 were presented in Table 3.

Table 3. Physicist Validation Result (Phase 2)

\begin{tabular}{|l|l|l|l|l|l|}
\hline No & Aspect & \multicolumn{2}{|c|}{ Appropriateness } & Average & Category \\
\cline { 3 - 5 } & $\begin{array}{c}\text { Expert } \\
\mathbf{1}\end{array}$ & $\begin{array}{c}\text { Expert } \\
\mathbf{2}\end{array}$ & & \\
\hline 1 & $\begin{array}{l}\text { Exercise } \\
\text { programs }\end{array}$ & $77 \%$ & $77 \%$ & $77 \%$ & $\begin{array}{l}\text { Very } \\
\text { valid }\end{array}$ \\
\hline 2 & $\begin{array}{l}\text { Exercise } \\
\text { videos }\end{array}$ & $75 \%$ & $75 \%$ & $75 \%$ & Valid \\
\hline 3 & $\begin{array}{l}\text { Exercise } \\
\text { evaluation }\end{array}$ & $75 \%$ & $75 \%$ & $75 \%$ & Valid \\
\hline \multicolumn{7}{|l|}{ Average } & $75.7 \%$ & $\begin{array}{l}\text { Very } \\
\text { valid }\end{array}$ \\
\hline
\end{tabular}

From the results of data analysis that has been obtained from physicists I and II with a percentage of $75.7 \%$ (seventy-five point seven), these results were obtained from certain aspects and then adjusted to the feasibility classification table and showed that the product of the development of player strength training soccer 12-16 years old is very valid because it meets the criteria and deserves to be tested.

Table 4 showed the result of media expert validation. The appropriateness of all aspects got $75 \%$. The product of developing strength training for soccer players aged 12-16 years has met the criteria of being quite valid and worthy of testing.

Table 4. Media Expert Validation Result

\begin{tabular}{|l|l|l|l|}
\hline No & \multicolumn{1}{|c|}{ Aspect } & Appropriateness & Category \\
\hline 1 & $\begin{array}{l}\text { Exercise } \\
\text { programs }\end{array}$ & $75 \%$ & Valid \\
\hline 2 & Exercise videos & $75 \%$ & Valid \\
\hline 3 & $\begin{array}{l}\text { Exercise } \\
\text { evaluation }\end{array}$ & $75 \%$ & Valid \\
\hline \multicolumn{2}{|l|}{ Average } & $75 \%$ & Valid \\
\hline
\end{tabular}

\subsection{Small Group And Large Group Trials}

Table 5 showed the result from field trials (small group and large group). The average score from small group trial was $80 \%$. It indicated that the product was very valid and ready to be tested. The same result was also gotten in the large group trial. This trial showed very valid result for the application tested.

Table 5. Field Trials Results

\begin{tabular}{|l|l|l|l|l|}
\hline No & Group & Aspect & $\begin{array}{c}\text { Appropria } \\
\text {-teness }\end{array}$ & Category \\
\hline 1 & \multirow{2}{*}{ Small } & $\begin{array}{l}\text { Exercise } \\
\text { programs }\end{array}$ & $77.8 \%$ & Very valid \\
\cline { 3 - 5 } & $\begin{array}{l}\text { Exercise } \\
\text { videos }\end{array}$ & $79.2 \%$ & Very valid \\
\cline { 3 - 5 } & $\begin{array}{l}\text { Exercise } \\
\text { evaluation }\end{array}$ & $83 \%$ & Very valid \\
\cline { 3 - 5 } & Average & $80 \%$ & Very valid \\
\hline
\end{tabular}




\begin{tabular}{|l|l|l|l|l|}
\hline No & Group & Aspect & $\begin{array}{c}\text { Appropria } \\
\text {-teness }\end{array}$ & Category \\
\hline 2 & Large & $\begin{array}{l}\text { Exercise } \\
\text { programs }\end{array}$ & $88.2 \%$ & Very valid \\
\cline { 3 - 5 } & $\begin{array}{l}\text { Exercise } \\
\text { videos }\end{array}$ & $89.6 \%$ & Very valid \\
\cline { 3 - 5 } & $\begin{array}{l}\text { Exercise } \\
\text { evaluation }\end{array}$ & $88 \%$ & Very valid \\
\cline { 3 - 5 } & & $88.68 \%$ & Very valid \\
\hline
\end{tabular}

\subsection{Revised Product Review}

The revised products include the number of training models that previously only 1 (one) to 4 (four). According to Contreras (2013) that the number of different muscle training models will meet the principle of variation. Then the implementation procedures that previously did not exist make it easier for athletes to apply the exercise movements presented in the android application, as stated by Sidik (2010) to overcome boredom, a series of exercise variations as a form of exercise to achieve success.

\subsection{Utilization Suggestions}

Suggestions for further utilization, athletes are expected to consult first with the coach regarding the desired strength training. So that when entering the strength training material and training program it is ready and the hope is that athletes are able to follow the available training procedures. And the coach knows and understands the condition of the athlete's strength, it can be provided with tests available in the bolafit application. In addition to applying strength training movements in other literature books related to the material on the strength of soccer players.

\section{DISCUSSION}

The sport that is played the most by the Indonesian people because it is the most popular is football (Amiq, 2019). With the special advantages of Indonesian players, namely fast, agile, and superior one by one (1v1) where the geographical and sociological culture also supports, namely the tropics, respect for the hierarchy, and high family ties [2].

From some of these statements, to maximize the advantages possessed, athletes must be managed by related parties, namely achieving achievements as explained by Walker that peaking athletes with such soccer training is not as expected, namely at the age of 12-16 years, due to athlete management problems and physiological limitations [4] The Football School in Malang, Arema Indonesia Training and Education in particular has students whose majority are aged 12-16 years. At this age, children have experienced puberty. Puberty is a period of dynamic development characterized by rapid changes in body size, shape and composition [13]. With this rapid growth and development, they must be guided and nurtured according to Saputro's statement that their Characteristics are having great physical growth, and have begun to convey their freedom and some of their rights to be expressed [19].

This strength training model was adapted from the Swinnen which contains a model of strength training that can be done [9]. From some of these exercise models, researchers developed an android application based on an Android application systematically. Finding this, in accordance with the development objectives. Development is the use of a science in order to produce a new product aimed at producing and developing a product [20], [21].

The contents of the android application consist of a strength training model (adaptation of anatomy, maximum strength, and power), an exercise program, and an evaluation of exercises that contain various tests related to the exercise program. The types of strength consist of: anatomical adaptation, maximal strength, and power [12]. Researchers developed a strength training model to get a physical expert test I and a physicist II obtained $82 \%$ with very valid criteria. The results of the media expert test validation obtained $75 \%$ with quite valid criteria. The small group test obtained $80 \%$ with very valid criteria, and the large group test results obtained $88.68 \%$ very valid. The results of the expert validation test with the results of field trials are directly proportional. Then the level of athlete satisfaction in the use of applications from various aspects available in the questionnaire provided via google form from small group trials with large groups there is a difference/ improvement. As a medium of practice, preliminary field testing (implementing initial trials) carried out with a certain scale (small group testing) involving 6 (six) to 12 (twelve) subjects [16]. This step of data collection was carried out by means of interviews, observations, or questionnaires and the next stage was Main Field Testing (large group trials), carrying out large group trials with the number of subjects from 30 to 100 people.

The development of this strength training consists of 38 (thirty eight) exercise models, each of which consists of a minimum of 4 (four) exercise models. These strength training models are packaged in the form of an android application called Bolafit to make it easier for athletes to exercise online or at home and also make it easier for coaches to use and develop training media used to improve the quality of soccer athletes' strength [12]. Media is a tool used as an intermediary to stimulate developmental aspects in children, especially motor skills [22]. This development is in line with the objectives of research and development, namely to meet the needs of Arema Indonesia's education and training related to the physical training of athletes aged 12-16 years.

\section{CONCLUSION}

The conclusion that can be drawn from this study is the product that was developed for strength training in 
soccer players aged 12-16 years, Arema Indonesia is applicable. With this product, it is hoped that it can help coaches in providing physical strength material to athletes in a systematic way.

\section{AUTHORS' CONTRIBUTIONS}

$\mathrm{MH}$ contributed to design and study selection, data collection, data analysis, and writing the manuscript. Meanwhile, MY and T contributed to validation, review, and writing the manuscript.

\section{ACKNOWLEDGMENTS}

The authors thank to Arema Indonesia and Faculty of Sport Sciences, Universitas Negeri Malang that support this study.

\section{REFERENCES}

[1] Amiq, F., Hariadi, I., \& Yudasmara, D. S. (2019). Pembentukan diklat (pendidikan dan latihan) sepakbola universitas negeri malang. 2(2), 3-6.

[2] Danurwindo., Putera, G., \& Sidik, B. (2017). Kurikulum Pembinaan Sepakbola Indonesia. Jakarta: Persatuan Sepak Bola Seluruh Indonesia.

[3] Arifin, Y. 2019. Para Usia 12 - 16 Tahun Sudah, Kapan Timnas Senior Juara Piala AFF?, (Online), (http://www.sport.detik.com/sepakbola ligaindonesia/d-4445849/para-Usia 12 - 16 Tahunsudah-kapan-timnas-senior-indonesia-juara-pialaaff), diakses pada tanggal 14 April 2020

[4] Walker, O. (2016). Peak Height Velocity. Science for Sport. Dari https://www.scienceforsport.com/peak-heightvelocity/\#toggle-id-1

[5] Balyi, I., \& Hamilton, A. (2004). Long-Term Athlete Development: Trainability in Childhood and Adolescence. Windows of Opportunity. Optimal Trainability. Training, 16(1), 1-6. Retrieved from http://www.athleticsireland.ie/content/wpcontent/uploads/2007/03/bayliLTAD2004.pdf\%5 Cnhttp://pellatrackclub.org/files/www.athleticsire land.ie_content_wpcontent_uploads_2007_03_bayliLTAD2004.pdf

[6] Lloyd, R.S., and Oliver, J.L. (2012). The Youth Physical Development Model: A New Approach to Long-Term Athletic Development. Strength and Conditioning Journal, 34(3), pp.61-72.

[7] Association, T. C. S. (2009). Canadian Soccer Association Long Term Player Development Wellness To World Cup. Retrieved from
https://www.canadasoccer.com/files/CSA_2009_ W2WC_Brochure_EN.pdf

[8] Purnama, S. K., Hariadi, I., Hariono, I., dll. (2017). Modul Pelatihan Pelatih Fisik Olahraga Level 1. Jakarta: Koni Pusat.

[9] Swinnen, B. (2016). Strength Training for Soccer. New York: Routledge.

[10] IFAB. (2017). 2017/18. Zurich: FIFA.

[11] Iskandar, R. P., \& Nasuka, H. (2015). Pengaruh Daya Ledak dan Latihan Kekuatan terhadap Hasil Jump Heading. Journal of Sport Sciences, 4(2), 28-33.

[12] Bompa, T. O., \& Haff, G. G. (2016). Periodization Theory and Methodology of Trainig (5th ed.). United States: Human Kinetics.

[13] Neinstein, Lawrence S. et.al. (2008). Adolescense Health Care: A ParticalGuide. Philadelphia: Lippincott Williams \& Wilkins.

[14] Setijowati, U., Marjuni, M., Asih, S. S., \& Witanto, Y. (2021, May). Strategi Pemberdayaan Guru SD dalam Mengelola Pembelajaran Di Masa Pandemi melalui Sejumlah Aplikasi Android. In Prosiding Seminar Nasional Institut Agama Hindu Negeri Tampung Penyang Palangka Raya (No. 3, pp. 212-224).

[15] Chistiyah, I., \& Priyanto, P. (2021). Pengembangan Alat Bantu Latihan Shooting dengan Aplikasi "My Basketball Coach" Berbasis Android. Journal of Sport Coaching and Physical Education, 6(1), 11-19.

[16] Borg, W.R. \& Gall, M.D. Gall. (1983). Educational Research: An Introduction, Fifth Edition. New York: Longman.

[17] Sugiyono. (2015). Metode Penelitian Kualitatif \& Kuantitatif dan R\&D. Bandung: Alfabeta.

[18] Akbar, Sa'dun. 2013. Instrumen Perangkat Pembelajaran. Bandung: Rosdakarya.

[19] Saputro, K. Z. (2018). Memahami Ciri dan Tugas Perkembangan Masa Remaja. Aplikasia: Jurnal Aplikasi Ilmu-Ilmu Agama, 17(1), 25. https://doi.org/10.14421/aplikasia.v17i1.1362

[20] Kantun, S. (2013). Hakikat dan Prosedur Penelitian Pengembangan.

[21] Nusa, P. (2011). Research \& Development. PT Raja Grafindo Persada.

[22] Dewi, K. (2017). Pentingnya Media Pembelajaran Usia Dini. 81-96. 